УДК $82.09(470)$

DOI 10.23951/1609-624X-2020-3-45-52

\title{
ПЕТЕРБУРГ ИВАНА ЕЛАГИНА
}

\section{А. А. Хадынская}

\section{Сургутский государственный университет, Сургут}

Введение. Рассматривается образ Петербурга в лирике Ивана Елагина, одного из заметных представителей второй волны эмиграции.

Цель - проследить развитие образа в его эволюции, зафиксировать «общие места» петербургской поэтики, вместе с тем отметить и личный вклад автора в разработку темы в условиях эмиграции.

Материал и методы. Методология исследования предполагает интерпретацию поэтических текстов с опорой на теоретико-литературоведческие понятия (акмеизм, литературная традиция, поэзия диаспоры и метрополии и пр.). Автор статьи также придерживался сравнительно-исторического метода при анализе текстов, сопоставляя стихотворения, имеющие приметы одного поэтического течения, но «разнесенных» во времени.

Результаты и обсуждение. Образ Петербурга в литературе русского зарубежья не раз становился предметом научных изысканий, но лирика Ивана Елагина еще не привлекала пристального внимания литературоведов в плане трактовки темы Петербурга с акмеистических позиций. Был рассмотрен ряд стихотворений поэта как яркий пример следования заветам акмеизма в условиях эмиграции, хотя в лирике Елагина не менее важен и авангардный элемент. Но в образе города на Неве поэт сознательно ориентируется на поэтику акмеизма, о чем говорят многочисленные аллюзии и тематические переклички со старшими акмеистами - Н. Гумилевым, А. Ахматовой, О. Мандельштамом.

Заключение. Лирическое воплощение образа Петербурга у Ивана Елагина продиктовано его акмеистической ориентацией и желанием вписать свое имя в ряд собственных поэтических учителей-акмеистов. Петербург Елагина актуализирует общие для «петербургского текста» установки, но, кроме того, демонстрирует эмигрантскую специфику в трактовке образа Северной Пальмиры. Доминирующей чертой образа становится его мортальность, устремленность в «потустороннее», отражение в нем экзистенциальной тоски и ностальгии - извечных «спутников» поэта-изгнанника.

Ключевые слова: Иван Елагин, поэзия русской эмиграиии второй волны, «петербургский текст», аллюзия, акмеистические традиции, тема смерти.

\section{Введение}

Петербург в русской культуре и литературе занимает особое место. Известный исследователь «петербургского топоса» В. Н. Топоров выявлял его специфику как возможность рассмотрения его как особого рода культурного текста сложной и антиномичной структуры. Эту антиномичность ученый объяснял «кровавой историей» города с противоречивой оценкой идеи его строительства; плохим климатом, вызывающим болезни, как физические, так и душевные; «криминальной репутацией», отраженной во множестве художественных текстов, и пр. [1]. Различные аспекты «культурного существования» города на Неве были отмечены в ряде серьезных фундаментальных исследований [2-5]. При всей разнице подходов авторы сходились в мысли об уникальности города и его особом влиянии на всю русскую культуру.

В XIX в. в русской литературе складывается «петербургская классика» (Пушкин, Гоголь, Достоевский и др.), заложившая основы так называемого «петербургского мифа», наделившего столицу России «архетипическими» составляющими: город имперской славы, город-призрак, город-каменный ансамбль с рядом узнаваемых архитектурных точек (Исаакиевский и Казанский соборы, Петропавлов- ская крепость, Адмиралтейство, Биржа, Медный всадник, Александровский столп и пр.), особый географический локус с яркими природными приметами (болота, низкое небо, ветер и пр.) и отличительными урбанистическими (Невский и прочие прямые проспекты, Васильевский остров, «Фальконетовы» мосты, Сенатская площадь и пр.).

«Мифологема» города полнилась на протяжении всей истории ее развития, и особая роль в этом принадлежит Серебряному веку, сделавшему Петербург центром своей культурной вселенной. Модернисты начала $\mathrm{XX}$ в., апеллируя к опыту русской классической литературы, внесли свой неоценимый вклад в создание нового культурного облика города - последнего оплота русской цивилизации, впоследствии ушедшей в небытие после октябрьского переворота 1917 г. Об этом русском «Титанике», утонувшем в кровавом море русской революции, писали практически все известные и малоизвестные литературные деятели первой трети XX в. Начало «новому мифу» о Петербурге положили символисты, поместив город, следуя духу времени, в эсхалогический контекст, придав ему «дьявольского флера». Мотивы распада, крушения, гибели, мировой катастрофы становятся доминирующими в изображении урбанистического топоса в симво- 
листском творчестве (А. Блок, А. Белый и др.). Постсимволистские течения по-своему интерпретировали образ столицы, в частности, акмеизм предложил возврат к «культурной памяти» города, акцентируя внимание на мифологемах «города-сада», «рая», «колыбели русской Европы» (А. Ахматова, Н. Гумилев, О. Мандельштам, В. Нарбут). «Петербургская тематика» расширилась в них за счет введения в поэтический оборот тематики пригородов (царскосельская и пр.). Исследованиям Петербурга в поэзии Серебряного века посвящены работы М. В. Безродного, 3. Г. Минц и А. А. Данилевского [6], Р. Д. Тименчика [7], Т. Н. Цивьян и др. [8].

Именно акмеизм, как в силу своей хронологии, так и в своей установке «тоски по мировой культуре», стал «хранителем» мифа о Петербурге во всей его исторической и мифологической полноте, несмотря на то, что век этого течения в России был недолог и закончился, по сути, с расстрелом Н. Гумилева в 1921 г. Во многом наследницей акмеистической «версии» Северной Пальмиры стала литература русской эмиграции, сохранившая его с особым пиететом и любовью.

В известной антологии Р. Тименчика и В. Хазана «Петербург в поэзии русской эмиграции» представлен весьма внушительный корпус стихотворений о городе, дающий представление о масштабе «петербургского текста» в беженской литературе $[9$, с. 23]. В предисловии к изданию исследователи выявляют составляющие собственно эмигрантского «мифа о Петербурге», обращая внимание на то, что он был порожден прежде всего эмиграцией первой волны (1917-1940), осознававшей себя «хранительницей» русской культуры за рубежом.

Резюмируя изыскания Р. Д. Тименчика и В. И. Хазана, обозначим главные аспекты «петербургского текста» русского зарубежья:

- сохранение города в памяти во всех его ощущениях (вкусовых, одористических, кинестетических, зрительных);

- Петербург - это город детства, воспоминания о котором базируются именно на детских впечатлениях, порой причудливых и нелогичных, но от этого еще более достоверных;

- Петербург как символ державности, мифического «эмигрантского государства», о котором грезили все «беженцы поневоле», пытаясь избыть эту горестную ситуацию эмиграции;

- город - «потерянный рай», откуда беженцы были изгнаны;

- Петербург связан с заветами Серебряного века, которые эмигрантам надлежит сохранять в изгнании;

- Петербург - символ «былого прошлого» (сложилось выражение «былой Петербург»), и все вос- поминания обретают ореол ценности старого, прошедшего. Тотальная ностальгия пронизывает все сферы жизни изгнанников на чужбине, включая даже такую необычную «приземленную сферу, как еда («кулинарная тоска»);

- Петербург связан с символикой смерти, включающей в себя различные вариации: место гибели великих поэтов (Пушкина, Блока, Гумилева), темы мученичества и насилия, связанные с революцией, плача о «мертвом городе» (гибели самого Петербурга), блокадного Ленинграда (у эмигрантов второй волны, переживших эту трагедию);

- Петербург как город, в который нужно (и очень хочется) вернуться, что стало заветной мечтой эмигрантов. Иногда они туда возвращаются (в снах и грезах), очень редко в реальности (как И. Чиннов, дважды посетивший Петербург, будучи эмигрантом, или как И. Одоевцева, воплотившая мечту о последнем приюте на петербургском кладбище). С этим связан мотив «неузнавания» города, сильно изменившегося с далеких революционных лет.

Если обобщить сказанное, то, как пишут Р. Д. Тименчик и В. И. Хазан, «Петербург для эмигрантского художественного сознания - это не только определенная географическая точка, не очередной «городской текст», это едва ли не метафизическое понятие, прикладываемое к разного рода видам и явлениям, дабы выведать, распознать, исследовать их душу, их «символ веры» [9, с. 7]. Это было особенно актуально для представителей первой волны эмиграции, покинувших родину во многом поневоле, не примирившихся с большевистским режимом или просто спасавших свои жизни. Но парадокс «петербургского мифа» в эмиграции заключался еще и в том, что его начинали разделять и те, для кого Петербург не был родным городом, и те, кто бывал в нем всего несколько раз, и те, кто долгие годы жил при советской власти и знал его как Ленинград, но потом покинул его после Второй мировой войны (представители второй волны эмиграции - так называемые «ди-пи»). К числу последних принадлежал Иван Елагин, посвоему воплотивший миф о великом Городе в своем поэтическом творчестве.

\section{Материал и методы}

Феномен Петербурга в лирике Ивана Елагина, с нашей точки зрения, следует рассматривать с учетом эстетической установки автора, ориентированного в своем творчестве как на акмеизм, так и на авангард, что выразилось в причудливом сочетании в его стихах разнородных литературных аллюзий и общем стилистическом многообразии. Кроме того, важную роль в трактовке петербургской темы сыграл и биографический фактор: хотя поэт жил в разных областях нашей обширной родины (Влади- 
восток, Харбин, Саратов, Киев), но в городе на Неве он неоднократно бывал и «присвоил» этот локус эстетически, успев почувствовать его влияние непосредственно. Интерпретация Елагиным образа Петербурга прослежена нами в его эволюции, от ранних сборников к поздним, отмечена многоаспектность в изображении столицы сообразно общей эмигрантской концепции «петербургского мифа».

\section{Результаты и обсуждение}

Биография Ивана Елагина (1918-1987) оказалась насыщена острыми драматическими моментами, как и у многих других представителей второй волны эмиграции, заставших полный трагизма отрезок в истории родной страны: развал Российской империи, установление советской власти и борьба с гитлеризмом во время Второй мировой войны. Исторические метаморфозы в судьбе поэта соединились с личными начиная с самого его рождения. Его отец, поэт-футурист и переводчик с китайского и японского Венедикт Матвеев (псевдоним Венедикт Март), известный незаурядными поступками и провокационным поведением, назвал сына Зангвильдом; имя не значилось ни в одном именнике и, вероятно, было сочинено им самим. От экзотического имени осталось домашнее прозвище Заяц, а в «миру» будущий поэт стал Иваном Венедиктовичем Матвеевым. Родительскую семью Ивана можно, вероятно, именовать неблагополучной: мать, Серафима Лесохина, врач, по слухам, была многократной пациенткой психиатрической лечебницы, погибла при неизвестных обстоятельствах во время блокады Ленинграда; отец воспитывал сына фактически в одиночку, перемещаясь с ним по стране, и в итоге своим эпатажным поведением довел себя до Бутырской тюрьмы, где и был расстрелян в 1937 г. Во время очередной «отсидки» отца, пристрастившегося к морфию и опиуму, Иван даже беспризорничал, пока его не обнаружил и не приютил один из приятелей родителя. Но поразительным образом Иван не только не пошел «по кривой дорожке», чему, казалось бы, ситуация способствовала, но и проявил себя как морально стойкий и умеющий выживать в любых условиях человек, к тому же серьезный поэт. Может, сказались гены его незаурядных родственников: известный дальневосточный поэт и переводчик-японист Николай Амурский приходился ему дедом, а не менее известная поэтесса Новелла Матвеева - двоюродной сестрой; крестным отцом Венедикта Матвеева был отец Даниила Хармса народоволец Иван Ювачев, и «дети» впоследствии общались.

Перед Великой Отечественной войной Иван переехал с отцом в Киев и на момент прихода туда фашистов окончил три курса местного мединсти- тута и был женат на поэтессе Ольге Штейнберг (Анстей). Во время оккупации он работал в родильном доме, тем самым сохранив себе жизнь (по матери он был евреем). В 1943 г. он эмигрировал в Германию, попал в лагерь для DP в американской зоне оккупации. Союзники не выдали обитателей лагеря сталинским властям, и Елагины начали жизнь эмигрантов. Семейная жизнь не сложилась, несмотря на рождение дочери Елены. Ольга Анстей вышла замуж за другого, но при переезде Ивана в 1950 г. в США они еще состояли в браке. В Америке Иван выживал с большим трудом, первоначально без знания языка, хватаясь за любую работу. Но природный талант позволил ему не только выучить английский, но и стать впоследствии профессором русской литературы Питтсбургского университета. Там же он нашел и личное счастье - женился на потомке русских эмигрантов Ирине Даннгейзер, которая родила ему сына Сергея и стала верной подругой до конца жизни.

Творческий путь Ивана Елагина начался еще в России, в 1941 г., с переводов с украинского стихотворений М. Рыльского, введшего начинающего автора в литературный круг. Но стихи этого периода почти неизвестны исследователям, как поэт Елагин сформировался за границей, и его творческое наследие составляет десять сборников («По дороге оттуда» (1947), «Ты, мое столетие» (1948), «По дороге оттуда» (1949), «Отсветы ночные» (1963), «Косой полет» (1967), «Дракон на крыше» (1973), «Под созвездием Топора» (1976), «В зале Вселенной» (1982), «Тяжелые звезды» (1986), «Курган» (1987)), сборник политической лирики «Политические фельетоны в стихах 1952-1959» (1959) и пьеса «Портрет Мадмуазель Таржи» (1949). Его произведения издавались в Германии и США, российские издания на данный момент представлены републикацией сборника 1986 г. «Тяжелые звезды» (Владивосток, 2012) и «Собранием сочинений» в двух томах (Москва, 1998) под редакцией Е. Витковского.

Иван Елагин был оценен как современниками, так и «старой эмиграцией». Последняя в свойственной ей манере отнеслась к представителю поэзии «ди-пи» с известным подозрением, как ко всему советскому. Известен отклик на его творчество Г. Иванова, поборника чистого «петербургского стиля», сразу увидевшего в нем «примесь» авангардизма: «Он находчив, боек, размашист, его стихи пересыпаны блестками удачных находок. Все опубликованное им до сих пор так же талантливо, как поверхностно, почти всегда очень ловко, но неизменно неглубоко». Заметная ориентация Елагина на лирику Маяковского получила у Г. Иванова отрицательную характеристику (он назвал его «не помнящим родства»), сами же стихи были восприняты как 
аванс читателю, но все же с признанием таланта («покуда всего лишь вексель, правда, размашисто выписанный на крупную сумму») [10, с. 25].

В дальнейшем стало ясно, что «ивановский вексель» вполне себя оправдал, Елагин вырос в настоящего русского поэта, авангардистский «крен» при этом стал отличительной меткой его поэтики, соединившей то, что во времена Серебряного века стояло по разные стороны культурных баррикад.

Из двух самых крупных имен второй волны русской литературной эмиграции, Дм. Кленовского и И. Елагина, Г. Иванов в своих критических отзывах как «своего» принял именно первого, неслучайно названного Н. Берберовой «последним царскоселом» - столь явственно прозвучала в его лирике петербургская нота, столь подробно воссоздан этот город в его в стихах и столь точно он наследовал знаменитой «петербургской поэтике» акмеистического толка, близкой самому Г. Иванову, о чем мы уже писали в нашей статье [11]. Петербург Ивана Елагина, несомненно, другого свойства, что объясняется и биографически (Кленовский действительно был царскоселом по рождению, а Елагин родился во Владивостоке и в Петербурге лишь иногда бывал), и эстетически (явная акмеистическая ориентация, практически без примесей, на «прекрасную ясность» у Кленовского, во многом контрастна с поэтикой Елагина, воплощавшего в собственных стихах новаторские авангардные решения). Но при всей разнице оба поэта оказались в силовом поле «петербургского мифа» эмигрантского толка и воспринимали Город как знак утраченной России и символ русской культуры.

Обозначение петербургской темы в лирике Елагина началось за границей, с выбора псевдонима. По свидетельству Ю. Богуславской, работавшей с Елагиным в конце 70-х гг. XX в. в колледже Мидделбери в штате Вермонт и близко его знавшей, псевдоним Елагин себе взял абсолютно случайно: в лагере для перемещенных лиц ему предложили публикацию в газете, нужно было подписаться, но «ему не захотелось давать свою подлинную фамилию - Матвеев. А на стене в редакции висела литография Елагина моста в Ленинграде. Так он выбрал свой псевдоним - Елагин» [12]. Подруга поэта, Людмила Титова, отчасти подтверждает «литературное» происхождение псевдонима, когда в своих мемуарах пишет, что псевдоним Елагин «был заготовлен еще до войны, по строке из Блока «Вновь оснеженные колонны, / Елагин мост и два огня...» [10, с. 20].

Случайность все-таки была не совсем случайной. В Петербурге Елагин жил наездами, сейчас трудно воспроизвести точную хронологию его многочисленных перемещений, но одно известно точно: в городе на Неве состоялась его историческая встре- ча с Ахматовой, которую он помнил всю жизнь; что касается ее, то здесь история умалчивает. По свидетельству его жены, Ольги Анстей, Елагин встретился с ней мельком, Анна Андреевна, по ее словам, спешила на встречу с сыном в тюрьму, слушать стихи расположена не была и отказала ему в наставничестве. Иван лишь успел сказать короткую речь и поцеловать ей руку, о чем оставил стихотворное воспоминание. Поэт пишет об Ахматовой с пиететом, не веря собственному счастью: «Я никогда не верил, / Что к Вам приведут пути. / Но Вы отворили двери, / К Вам можно было войти» [13, с. 17].

Увлечение Ахматовой было знаком общей акмеистической ориентации Елагина, о чем во многом говорит его вклад в «петербургский текст». На страницах его сборников город на Неве оживает именно в акмеистическом варианте: как известно, это течение декларировало синтез слова и визуального образа, акмеисты активно пользовались приемом экфрасиса, создавали словесные картины, апеллировали к живописным приемам, искали им словесные эквиваленты. «Живописность», стремление описать пейзаж или жизненную сценку как картину, акцент на визуальном восприятии действительности - эти качества лирики Елагина демонстрируют его акмеистическую направленность, о чем еще в 1994 г., когда о Елагине очень мало знали на родине, написал А. Б. Соктоев, обращая внимание на общую тенденцию активного влияния поэтики акмеизма на творчество авторов «первой волны» эмиграции и попавшую под это влияние лирику Елагина, принадлежавшего к поколению «второй волны». Исследователь указывает: «Ведь тогда, в 20-30-е гг. преобладающее влияние на зарубежную русскую поэзию оказывал опыт акмеизма и шире - постсимволистской поэтической школы, одной из неизменных примет которой была живописная, изобразительная природа поэтического образа. Во многом на этих же принципах строится поэтический образ в стихотворениях И. Елагина. Постоянный иллюстратор его книг, талантливый художник С. Л. Голлербах, отмечая пристрастие своего друга к живописным приемам, подчеркивал, что «в своей поэзии Иван Елагин употреблял... приемы живописца и графика. Он знал мазок, линию, экспрессивный контраст...» [14].

В процитированном стихотворении, посвященном Ахматовой, тоже возникает живописная деталь, которая становится для поэта знаком культурного прошлого: «И над простым диваном / Девушки в белом портрет». Догадка пришла к герою уже на обратном пути: «Я понял уже в воротах, / Что девушка в белом - Вы» [13, с. 17]. Диалог не состоялся, но для героя-поэта важно было хотя бы увидеть и прикоснуться к своему кумиру: «И, подавляя муку, / Глядя в речной провал, / Был счастлив, 
что Вашу руку / Дважды поцеловал» [13, с. 17].

Контрастом выглядит описание живой Ахматовой в пересказе Ольги Анстей: «Одета она была в шелковое трикотажное, но совершенно драное, разлезшееся платье, длинное, темное» [13, с. 17]. Для поэта контраст был принципиально важен, как знак «водораздела» - «было» и «стало». У Елагина память о прошлом во многом базируется на подобных визуальных приметах, цепко сидящих и настойчиво бьющихся в его мозгу, как у всех эмигрантов первой и второй волн: мемуарные свидетельства, прозаические или стихотворные, всегда представляют из себя «картины жизни», сопряженные с мощным комплексом эмоциональных переживаний.

Р. Тименчик и В. Хазан обращают внимание на то, что эмигранты создали свой петербургский текст, маркированный знаком ностальгии по навсегда ушедшему Городу, на принципиально визуальных характеристиках: «Петербургский поэтический эмигрантский текст, встающий в позицию самооглядки, берущий на себя обязанность резюмировать и сгустить традицию, усиливает тенденцию экфразиса, описание картины города, точнее города как картины» $[9$, с. 23]. В этот контекст «зримого» образа Северной Пальмиры оказались «втянуты» и прочие характеристики, в частности, кинестетическая, одористическая, а также «вещная» - верный знак акмеистической природы «петербургского текста», когда город предстает в обилии разнообразных деталей, зримых знаков, топографических примет, ставших уже фактически мифологическими. На акмеистичность поэтического взгляда на мир Ивана Елагина указывает и В. Агеносов: «Он свободно и легко писал из слов картины, его поэзия ,зряча“"». При всей простоте своего творчества Елагин умел четко обрисовать все, что хотел, обрушивая на читателя „звездопады“ строк и превращая его в зрителя» [15, с. 435].

Эмигрантский «петербургский миф» смысловой доминантой имеет антитезу родины и чужбины, причем сравнение большей частью не в пользу последней. В те страшные годы беженство казалось спасением, но после неустроенного житья на новом месте, даже при более-менее благоприятных обстоятельствах (как, например, у Елагина в конце жизни), ностальгия только усилилась. Образ города обрел черты сакральности и заимел «эдемскую атрибутику»: урбанистические пейзажи стали напоминать райские кущи, город оказался внеположен времени и пространству и вызывал ощущение блаженства при воспоминании о нем. Эмиграция как «изгнание из рая» для беженцев воспринималась амбивалентно: в физическом смысле это было спасением, в духовном - смертью, ибо теперь весь оставшийся жизненный путь превратился в мучительное движение к трагической развязке.
С Петербургом традиционно в русской литературе связаны темы мистики, инфернальности, измененных психических состояний, двойничества. Одним из аспектов «петербургского текста» становится театральный дискурс, связанный с мортальной тематикой (русская классика XIX в. - драма М. Ю. Лермонтова «Маскарад», опера П. И. Чайковского на пушкинской сюжет «Пиковая дама» и пр.). В стихотворении «Я сначала зашел в гардероб...» (сб. «Дракон на крыше») лирический сюжет связан с посещением героем театра, и уже в первой строке появляется мистическая тема смерти, авторская вариация «сошествия во ад»: герой сдает в гардероб свой «крест» и свой «гроб», сам театр представлен как «ночной», с плывущей «хрустальной люстрой». Образ героя раздваивается, он и зритель, и актер («Где в толпе в амплуа я одном / А на сцене в другом амплуа»). Декорации он приносит с собой - это звезды, одну из них он привешивает «к девятнадцатому этажу». Герой видит себя со стороны «нанизанным» на синий луч («Сквозь меня он как нитка продет, / И в луче я почти неживой») - перед нами авторская метафора смерти. Петербург представлен в сравнении с Нью-Йорком: поэт рисует урбанистический пейзаж мегаполиса, напоминающий герою потустороннее пространство, в глубинах которого он видит очертания знакомого русского города: «И вплывает нью-йоркский рассвет / Прямо в белую ночь над Невой». Он обращается к созвездиям «как в адресный стол», ибо звезды - его ушедшие друзья («Но не ждут уже больше друзья»); в «том» мире, где уже прошел «ветер времени», только «стужа голосит» и «опущенный в прошлое мост» / Над рекою забвенья висит» [13, с. 417].

Театральные мотивы в мортальном ключе многократно потом встретятся в лирике Елагина вкупе с традиционной для эмигрантской поэзии темой одиночества. В стихотворении «На площади танцуют и казнят...» (сб. «В зале Вселенной») мортальная тема разворачивается в контексте ярмарочного балагана, городской площади, отличающейся известной «многофункциональностью»: на ней веселится толпа вместе с «площадным шутом» и «площадной шлюхой», там же торгуют по выходным дням и казнят по надобности. Герой зовет покупателя/читателя на свое представление: «Не хочешь ли билет в театр души, / Который я зову театром пыток?». Он, поэт, торгует «стихом, душою, строчкою» и риторически спрашивает: «Не надо ли кому-нибудь тоски?». Карнавальная семантика, подразумевающая амбивалентность жизни и смерти, сопрягается у Елагина с «площадной» тематикой Петербурга, также связанной с мучениями, физическими и духовными (например, общеизвестная Сенная площадь, где покаялся Раскольников и где били некрасовскую «крестьянку молодую»). 
В последней строфе содержится резюме о горькой доле «актера-эмигранта», лишенного своего «зрителя»: «Я там веду с собой разговор, / В моем театре я распорядитель, / И композитор я, и осветитель, / И декоратор я, и режиссер, / И драматург я, и актер, и зритель...» [16, с. 41-42].

Его «театр одного актера» символизирует безмерное эмигрантское одиночество, нередко толкающее на самоубийство. В елагинском варианте это одиночество носит экзистенциальный характер и является метафорой смерти. В стихотворении «Мой театр ослепительно умер...» (сб. «Дракон на крыше») герой играет свой последний спектакль, «развлекаясь в одиночку»: «Итак, представим мизансцену: / Мое окно выходит в стену. / Стена. Веревка для белья. Окно. Стена. Веревка. Я.» [13, c. 245]. «Петербургский текст» в этом стихотворении представлен имплицитно, в образе «желтого дома», где, по версии героя, он может находиться, пытаясь «обмануть время», перед тем, как «уплыть в одиночество», то есть умереть.

Тему смерти у Елагина также поддерживает изображение классического петербургского трамвая, отсылающего, помимо всех прочих, прежде всего к одному из самых известных акмеистических «транспортов» - к гумилевскому петербургскому и мандельштамовскому московскому. Стихотворение Елагина «Сам я толком не знаю...» (сб. «Тяжелые звезды») повторяет гумилевский лирический сюжет «Заблудившегося трамвая» (1919): герой вскакивает на подножку трамвая, «сбившегося с маршрута» (ср. у Гумилева «он заблудился в бездне времен»). Гумилевский трамвай символизирует неизбежность трагических исторических событий, в которые вовлечен герой; он сам вскочил на его подножку, и трамвай несет его к смерти. В стихотворении нагнетается мортальная символика («вороний грай», «огненная дорожка», «панихида по мне»), герой видит собственную гибель от революции («В красной рубашке, с лицом как вымя, / Голову срезал палач и мне»), которая представлена как стихийная сила, несущаяся без цели и выбранного направления, губящая ее вольных и невольных участников («И трудно дышать, и больно жить») [17, с. 218-219]. Аллюзивно прослеживается у Елагина и «трамвайная тема» О. Мандельштама. Начатая поэтом еще в 1915 г. (знаменитый «такой пустой, такой восьмой» в шуточном четверостишии), она косвенно продолжилась в «Концерте на вокзале» (1921) (упоминается «вагон», но поезда, который «торжественно уносится» в «Элизиум туманный») и в детских стихах «Два трамвая» (1924), где герои - забавные трамваи Клик и Трам. В микроцикле «Трамвай» (1926), также адресованном детям, есть стихотворения «Мальчик в трамвае», «Все в трамвае» и «Сонный трамвай». В пер- вом из трех упомянутых мы встречаем персонажаребенка, который правильно посчитал сдачу с гривенника, после чего «Трамвай поехал дальше / И в нем поехал мальчик» [18, с. 460]. Трагическое звучание образ едущего в трамвае уже «выросшего» мальчика получает в стихотворении «Нет, не спрятаться мне от великой муры...» (1931), словно завершая историю гумилевского трамвая революции, доехавшего до «курвы-Москвы». Маршуты «А» и «Б», по которому поедут герой и его воображаемый собеседник «посмотреть, кто скорее умрет», являются кольцевыми, они ходили по Садовому и Бульварному кольцу, отчего герой и не может никуда спрятаться и уже не видит смысла собственной жизни («И не знаю, зачем я живу...»). Себя он называет «трамвайной вишенкой страшной поры»заточенным в вагоне маленьким живым теплокровным существом в этом трамвае мертвецов, которое никогда не сможет выскочить из замкнутого адова круга [19, с. 165].

Елагин, продолжая аллюзивный диалог, присоединяется к этому поэтическому «трамвайному братству» и оказывается окруженным странными реалиями («карусели каштанов», «домов толкотня», «блестки звездных колючек», «пляс осенней трухи»), которые «обступили» его, «всюду нагрянув». Герой дезориентирован и не может понять собственное местоположение. Его трамвай «непутевый» в прямом смысле этого слова - у него нет выбранной траектории движения, он с громом и скрежетом едет «С одного перевала / На другой перевал», то есть преодолевает препятствия. Отрефлексированный образ трамвая символизирует его эмигрантское поэтическое слово миру; обращаясь к «прежним трамваям», он держится традиции, «сигналит» о преемственности («Мне не выдумать лучших, / Чем вот эти стихи»), внося свою лепту в «петербургский миф». Апелляция к знаковым акмеистическим текстам, с его точки зрения, придает вес собственным стихам, потому как для поэта единственной достойной формой существования является творчество: «И, пожалуй, что в этом / Биография вся: / Оставался поэтом, / На подножке вися» $[13$, с. 238$]$.

\section{Заключение}

Таким образом, с одной стороны, Петербург Ивана Елагина демонстрирует свою «вписанность» в традицию «петербургского текста», о чем свидетельствует обращение к устойчивым мотивам и образам, связанным с городом на Неве в русской культуре. С другой стороны, поэт разрабатывает образ города в эмигрантском контексте, указывая на совершенно новые «творческие обстоятельства», придающие городу экзистенциальную и ностальгическую эстетику. 


\section{Список литературы}

1. Топоров В. Н. Петербург и «Петербургский текст русской литературы» // Топоров В. Н. Миф. Ритуал. Символ. Образ: Исследования в области мифопоэтического: Избранное. М.: Прогресс-Культура, 1995. С. 259-367.

2. Анциферов Н. П. Душа Петербурга. Пб.: Брокгауз-Ефрон, 1922. 226 с.

3. Анциферов Н. П. Быль и миф Петербурга. Пб.: Брокгауз-Ефрон, 1924. 84 с.

4. Долгополов Л. Миф о Петербурге и его преобразование в начале XX века // На рубеже веков. О русской литературе конца ХІХ - начала ХХ в. Л., 1977. С. 158-204.

5. Федотов Г. П. Лицо России. Статьи 1918-1930. 2-е изд. Paris: YMCA-PRESS, 1988. 330 c.

6. Минц 3. Г., Безродный М. В., Данилевский А. А. «Петербургский текст» и русский символизм // Ученые записки Тартуского гос. ун-та. 1984. № 664. С. 78-92.

7. Тименчик Р. Д. «Поэтика Санкт-Петербурга» эпохи символизма/постсимволизма // Ученые записки Тартуского гос. ун-та. 1984. № 664. С. 117-124.

8. Тименчик Р. Д., Топоров В. Н., Цивьян Т. Н. Сны Блока и «петербургский текст» начала XX века // Тезисы I Всесоюзной (III) конференции «Творчество А. А. Блока и русская культура ХХ века». Тарту, 1975. С. 129-135.

9. Тименчик Р., Хазан В. На земле была одна столица // Петербург в поэзии русской эмиграции (первая и вторая волна) / вступ. ст., сост., подгот. текста и примеч. Р. Тименчика и В. Хазана. СПб.: Академический проект, Изд-во ДНК, 2006.848 c.

10. Витковский Е. Состоявшийся эмигрант // Елагин И. Собрание сочинений: в 2 т. М.: Согласие, 1998. Т. 1. С. 5-40.

11. Хадынская А. А. Образ Петербурга в лирике Дмитрия Кленовского // Мировая литература глазами современной молодежи. Цифровая эпоха: сб. материалов IV Междунар. молодеж. науч.-практ. конф. Магнитогорск, 2018. С. $215-221$.

12. Богуславская Ю. Иван Елагин (интервью) // Слово/Word. 2005. № 47. URL: http://magazines.russ.ru/slovo/2005/47/bo8.html (дата обращения: 31.01.2020).

13. Елагин И. Собрание сочинений: в 2 т. М.: Согласие, 1998. Т. 1. 464 с.

14. Соктоев А. Б. Талант, соединяющий поколения. URL: http://www.prometeus.nsc.ru/science/schools/soktoev/works/1994. ssi\#02 (дата обращения 31.01.2020).

15. Агеносов В. В. Иван Елагин (Матвеев). «Здесь чудо все: и небо, и земля...» // Агеносов В. В. Литература русского зарубежья (1918-1996). М.: Терра. Спорт, 1998. 543 с.

16. Елагин И. Собрание сочинений: в 2 т. М.: Согласие, 1998. Т. 2. 382 с.

17. Гумилев Н. С. Полное собрание сочинений в одном томе. М.: АЛЬФА-КНИГА, 2011. 1148 с.

18. Мандельштам О. Собрание сочинений: в 4 т. М.: ТЕРPА, 1991, Т. II. 730 с.

19. Мандельштам О. Собрание сочинений: в 4 т. М.: ТЕРРА, 1991. Т. І. 684 с.

Хадынская Александра Анатольевна, кандидат филологических наук, доцент, Сургутский государственный университет (ул. Ленина, 1, Сургут, Тюменская область, 628412). E-mail: opus2000@mail.ru

Материал поступил в редакиฺию 03.02.2020.

\section{DOI 10.23951/1609-624X-2020-3-45-52}

\section{PETERSBURG OF IVAN ELAGIN}

\section{A. A. Khadynskaya}

\section{Surgut State University, Surgut, Russian Federatoin}

Introduction. The article considers the image of St. Petersburg in the lyrics of Ivan Elagin, one of the prominent representatives of the second wave of emigration.

The objectives of the study are: to trace the development of the image in its evolution, to fix the "common places" of St. Petersburg poetics, at the same time to note the author's personal contribution to the development of the theme in conditions of emigration.

Material and methods. The research methodology involves the interpretation of poetic texts based on theoretical and literary concepts (acmeism, literary tradition, poetry of the diaspora and the metropolis, etc.).

Results and discussion. The image of St. Petersburg in the literature of the Russian abroad has repeatedly become the subject of scientific research, but the lyrics of Ivan Elagin have not yet attracted the close attention of literary scholars in interpreting the theme of St. Petersburg from acmeistic positions. We considered a number of his poems as a vivid example of following the precepts of acmeism in conditions of emigration, although the avant-garde element is no less important in the lyrics of Elagin. But in the image of the city on the Neva, the poet deliberately focuses on the poetics of acmeism, as evidenced by numerous allusions and thematic exchanges with senior acmeists - N. Gumilev, A. Akhmatova, O. Mandelstam. 
Conclusion. The lyrical embodiment of the image of St. Petersburg by Ivan Elagin is dictated by his acmeistic orientation and the desire to write his name in a line of his own poetic acmeist teachers. St. Petersburg of Ivan Elagin actualizes the general settings for the "St. Petersburg text", but, in addition, demonstrates the emigrant specificity in interpreting the image of Northern Palmyra. The dominant feature of the image is its mortality, striving for "beyond", the reflection in it of existential longing and nostalgia - the eternal "companions" of the exiled poet.

Keywords: Ivan Elagin, poetry of Russian emigration of the second wave, "St. Petersburg text", allusion, acmeistic traditions, the theme of death.

\section{References}

1. Toporov V. N. Peterburg i "Peterburgskiy tekst russkoy literatury" [Petersburg text of Russian literature]. In: Toporov V. N. Mif. Ritual. Simvol. Obraz: Issledovaniya v oblasti mifopoyeticheskogo: Izbrannoye [Myth. Ritual. Symbol. Image: Mythopoetic Studies: Favorites]. Moscow, Izdatel'skaya gruppa Progress-Kul'tura Publ., 1995. Pp. 259-367 (in Russian).

2. Antsiferov N. P. Dusha Peterburga [Soul of Petersburg]. Petersburg, Brokgauz-Efron Publ., 1922. 226 p.

3. Antsiferov N. P. Byl' i mif Peterburga [The Story and Myth of St. Petersburg]. Petersburg, Brokgauz-Efron Publ., 1924. 84 p. (in Russian).

4. Dolgopolov L. Mif o Peterburge i ego preobrazovaniye v nachale XX veka [The myth of St. Petersburg and its transformation at the beginning of the XX century]. In: Dolgopolov L. Na rubezhe vekov. O russkoy literature kontsa XIX - nachala XX v. [At the turn of the century. About Russian literature of the late XIX - early XX century]. Leningrad, 1977. Pp. 158-204 (in Russian).

5. Fedotov G. P. Litso Rossii. Stat'i 1918-1930 [The face of Russia. Articles 1918-1930]. Paris, YMCA-PRESS Publ., 1988.330 p. (in Russian).

6. Mints Z. G., Bezrodnyy M. V., Danilevskiy, A. A. "Peterburgskiy tekst" i russkiy simvolizm ["Petersburg text” and Russian symbolism]. Uchenye zapiski Tartuskogo gosudarstvennogo universiteta, 1984, no. 664, pp. 78-92 (in Russian).

7. Timenchik R. D. "Poetika Sankt-Peterburga" epokhi simvolizma/postsimvolizma ["Poetics of St. Petersburg" era of symbolism/ post-symbolism]. Uchenye zapiski Tartuskogo gos. un-ta, 1984, no. 664, pp. 117-124 (in Russian).

8. Timenchik R. D., Toporov V. N., Tsyv'yan T. N. Sny Bloka i "peterburgskiy tekst” nachala XX veka [Dreams of A. Blok and the "Petersburg text" of the early twentieth century]. Tezisy I Vsesoyuznoy (III) konferentsii "Tvorchestvo A. A. Bloka i russkaya kul 'tura XX veka” [Abstracts of the All-Union (III) Conference "A.A. Blok and Russian culture of the twentieth century"]. Tartu, 1975. Pp. 129-135 (in Russian).

9. Timenchik R., Khazan V. Na zemle byla odna stolitsa [There was one capital on earth]. Peterburg v poezii russkoy emigratsii (pervaya i vtoraya volna). Vstup. st., sost., podgot. teksta i primech. R. Timenchika i V. Khazana [Petersburg in the poetry of Russian emigration (first and second wave). Entry art., comp., text and notes preparation by R. Timenchik and V. Khazan]. Saint Petersburg, Akademicheskiy proyekt, Izd-vo DNK Publ., 2006. 848 p. (in Russian).

10. Vitkovskiy E. Sostoyavshiysya emigrant [The accomplished emigrant]. In: Elagin I. Sobraniye sochineniy: v 2 t. T. 1 [Collected works: in 2 volumes. Vol. 1]. Moscow, Soglasiye Publ., 1998. Pp. 5-40 (in Russian).

11. Khadynskaya A. A. Obraz Peterburga v lirike Dmitriya Klenovskogo [The image of St. Petersburg in the lyrics of Dmitry Klenovsky]. Mirovaya literatura glazami sovremennoy molodezhi. Tsifrovaya epokha: sbornik materialov IV Mezhdunarodnoy molodezhnoy nauchno-prakticheskoy konferentsii [World literature through the eyes of modern youth. Digital Age: Compendium of Informational Materials of the International Youth Scientific and Practical Conference]. Magnitogorsk, 2018. Pp. $215-221$ (in Russian).

12. Boguslavskaya Yu. Ivan Elagin (interv'yu) [Ivan Elagin (interview)]. Slovo/Word, 2005, no. 47 (in Russian). URL: http:// magazines.russ.ru/slovo/2005/47/bo8.html. (accessed 31 January 2020).

13. Elagin I. Sobraniye sochineniy: v 2 t. T. 1 [Collected Works: in 2 vols. Vol. 1]. Moscow, Soglasiye Publ., 1998. 464 p. (in Russian).

14. Soktoyev A. B. Talant, soyedinyayushchiy pokoleniya [Talent that connects generations] (in Russian). URL: http://www.prometeus.nsc.ru/science/schools/soktoev/works/1994.ssi\#02 (accessed 31 January 2020).

15. Agenosov V. V. Ivan Elagin (Matveyev). "Zdes' chudo vse: i nebo, i zemlya..." [Ivan Elagin (Matveev). "Everything is a miracle here: both the heaven and the earth...”]. In: Agenosov V. V. Literatura russkogo zarubezh'ya (1918-1996) [Literature of the Russian abroad (1918-1996)]. Moscow, Terra. Sport Publ., 1998. 543 p. (in Russian).

16. Elagin I. Sobraniye sochineniy: v 2 t. T. 2 [Collected Works: in 2 vols. Vol. 2]. Moscow, Soglasiye Publ., 1998. 382 p. (in Russian).

17. Gumilev N. S. Polnoye sobraniye sochineniy v odnom tome [Complete collection of works in one volume]. Moscow, AL'FAKNIGA Publ., 2011. 1148 p. (in Russian).

18. Mandel'shtam O. Sobraniye sochineniy v chetyrekh tomakh. T. II. [Collected works in four volumes. Vol. II]. Moscow, TERRA Publ., 1991. 730 p. (in Russian).

19. Mandel'shtam O. Sobraniye sochineniy v chetyrekh tomakh. T. I. [Collected works in four volumes. Vol. I]. Moscow, TERRA Publ., 1991. 684 p. (in Russian).

Khadynskaya A. A., candidate of philology, associate professor, Surgut State University (ul. Lenina, 1, Surgut, Russian Federation, 628412). E-mail: opus2000@mail.ru 